\section{Grei bok som kanskje bør suppleres}

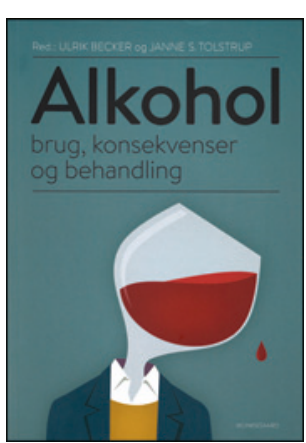

Ulrik Becker,

Janne Schurmann Tolstrup, red.

Alkohol

Brug, konsekvenser og behandling

408 s, tab, ill. København: Munksgaard, 2016.

Pris DKK 395

ISBN 978-87-628-1353-3

Siktemålet med denne danske utgivelsen er å være lærebok for personell som skal arbeide med alkoholproblemer og oppslagsbok for andre som er interessert i temaet. Det er 29 kapitler skrevet av 16 forfattere, blant dem flere internasjonalt anerkjente forskere, som Morten Grønbæk og Kim Bloomfield.

I større eller mindre grad dekkes de fleste aspekter ved alkoholfeltet, som historikk, epidemiologi, biokjemi, diagnostiske overveielser, (dansk) lovgivning, komorbiditet, forebygging, kroppslige og sosiale skadevirkninger og alkoholbruk hos ungdom og gravide. Bare få temaer er helt utelatt, som de sosialpsykologiske motivene for alkoholbruk og forskningen om alkoholens mulige virkninger på atferd og sinnsstemning.

Tyngdepunktet ligger på alkoholavhengighet og behandling av det. Overordnede samfunnsperspektiver er også til stede, selv om det er relativt lite fremtredende. Det gjelder blant annet hovedkonklusjonen i internasjonal alkoholforskning - nemlig at utviklingen av gjennomsnittsforbruket i stor grad styrer utviklingen av de målbare skadene. Dette er som kjent vist for alkohol, som det også er for mange andre risikofaktorer, for eksempel røyking.

I et eget kapittel om hvorvidt alkohol kan forebygge hjertesykdom er referansene stort sett begrenset til kohortstudier og til relativt gammel forskning. Her mangler viktig forskning fra de senere år.

Behandling i ulike rammer er gitt egne kapitler. Det er kapitler om behandling og kort intervensjon i allmennpraksis, og også om familiebehandling. Psykososial behandling er avspist med 20 sider. Farmakologisk behandling får derimot 24 sider, og fremstillingen er betydelig mer optimistisk enn det de senere års Cochrane-studier viser.

Alt i alt inneholder Alkohol mye interessant og relevant stoff, men den bør vel på noen områder suppleres med litteratur som trekker inn forskning som er uteglemt $\mathrm{i}$ denne utgivelsen.

\section{Hans Olav Fekjær}

Psykiater

Nesodden

\section{Glitrende om parakliniske og diagnostiske fag}

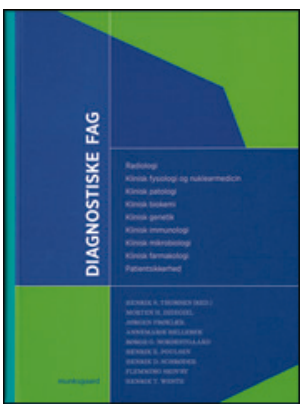

Henrik S. Thomsen, red.

Diagnostiske fag

392 s, tab, ill. København: Munksgaard, 2016.

Pris DKK 475

ISBN 978-87-628-1461-5

Forfatterne henvender seg i denne læreboken spesifikt til medisinstudentene ved de fire danske fakultetene, men våre norske medisinstudenter er absolutt i målgruppen. I tillegg er den utmerket for oppdateringer, både for yngre leger i spesialisering og - ikke minst - for lærere. I realiteten er denne utgivelsen nyttig for oss alle.

Det står til sammen ni hovedforfattere med 21 medforfattere bak de ti kapitlene. De omfatter de parakliniske fagene radiologi og generell bildediagnostikk, den kliniske delen av biokjemien, fysiologi/nukleærmedisin, genetikk, klinisk immunologi, mikrobiologi og farmakologi. Pasientsikkerhet er også diskutert. Diagnostiske fag er velskrevet, lett å lese og åpner for spennende muligheter i kunnskap om diagnostikk.

Innholdsfortegnelsen er sjeldent god og konkret, det samme gjelder stikkordsregisteret. Det er lett å finne frem, og den er nydelig illustrert med et usedvanlig rikt og nyttig bildemateriale.

Bare urogenitalsystemet i radiologikapitlet har fått 15 sider, med totalt 71 flotte CT-bilder av ulike kliniske tilstander og med en summarisk betraktning om de hyppigste indikasjonsstillinger. Tilsvarende for kapitlet klinisk fysiologi med indikasjonsstillinger for bruk av scintigrafiske metoder, som for eksempel undersøkelse av knokler med scintigrafiske eller PET-baserte undersøkelser ved ulike lidelser. Indikasjon og undersøkelsesprinsipp samt tolkning og klassifisering diskuteres ved osteodensitometri, som brukes for å bestemme mineralinnholdet i benvev. I kapitlet om klinisk patologi omtales flere ulike teknikker, men det mest interessante - som burde vekke gløden for faget - er de mikroskopiske bildene i ulike pasienthistorier. Den kliniske tilnærmingen er også tydelig i klinisk biokjemi og klinisk genetikk, illustrert med pasienthistorier og bilder.

Det kliniske arbeidet er helt avhengig av diagnostikken i de parakliniske fagene - og at de er viktige, kommer tydelig frem. For å oppnå gode resultater til beste for pasientene må man arbeide på tvers av spesialiteter. I boken omtales klinisk relevant og praktisk tilnærming til bruk av diagnostiske metoder.

Ved kjøp får man tilgang på en såkalt e-bok i 48 måneder. Det er en digitalisert versjon som kan lastes på PC, laptop eller smarttelefon. Denne boken med e-boktilgang anbefales på det varmeste, ikke bare for studenter, men kanskje enda mer for yngre leger.

Ingrid Os

Professor, Det medisinske fakultet

Universitetet i Oslo 